\title{
Management Infrastructure Facilities of Production Units "Musaba Authorized" in SMK Muhammadiyah 1 Bantul
}

\author{
Hilda Sabrina Nirwanti ${ }^{1, *}$ Zainal Arifin ${ }^{2}$ \\ ${ }^{1,2}$ Department of Education Management, State University of Yogyakarta \\ *Email: Hilda11006210@gmail.com,zainal_arifin@uny.ac.id
}

\begin{abstract}
Vocational High School is one part of the national education system that prepares workers with special skills needed by the business world. The Production Unit is one of the learning media in vocational high schools which functions as a place of production. This research was conducted with the aim of knowing the management of the vocational school production unit facilities, planning, implementing and supervising the vocational school production unit. This study used a qualitative research method with the type of case study research by conducting in-depth exploration of the management of production unit infrastructure at SMK Muhammadiyah 1 Bantul, as well as the usefulness of the production unit infrastructure in both schools as a source of student learning. Collecting data through observation, interviews, documentation and questionnaires. This study uses the interactive analysis model of Miles, Huberman and Saldana which includes data collection, data condensation, data presentation and drawing conclusions. The results of this study indicate that the production unit at the school is able to provide benefits for students, especially as a medium for student learning. the results of research that show: 1. Planning begins with budget planning, planning the needs of goods and materials for the Production Unit. 2. Organizing in the Authorized Musaba Production Unit has been carried out, the working mechanism is adjusted to the job description. 3. Implementation of the Musaba Authorized Production Unit includes: The division of tasks for teachers and educators, learning tools, learning orders, maintenance of production units, inventory, elimination, inventory of tools and machines, repairs and maintenance, time to use tools and machines. 4. Supervision of practical facilities and infrastructure is carried out by the Head of the Production Unit on a regular basis, assisted by technicians assigned to work in the workshop every day.
\end{abstract}

Keywords: Management, Management of infrastructure facilities, Production Unit, Vocational High School

\section{INTRODUCTION}

Vocational High Schools are part of the national education system that prepares workers with special skills needed by entrepreneurs [5] [7]. The growth of SMK in 2013 was 11,708 , the target of the SMK Directorate according to the 2010-2014 Vocational Education Development Roadmap, in 2014 there were 11,748 SMKs with 4,512,063 students and 219,000 teachers (Directorate of Vocational Development) [5] The growth in the number of SMKs in Indonesia is not accompanied by the quality of graduates according to their fields of expertise. The quality of SMK graduates has not been able to fill the needs of the business world and the industrial world, because the skills they have do not meet the standards required by the job market.
Productive practice learning has not been emphasized on entrepreneurial attitudes, entrepreneurial learning is still theoretical, production units have not been managed properly and optimally to support learning [5]; [10];[7]. One solution to the problem above is to optimize the production unit to stimulate student entrepreneurial attitudes. The government must provide full support to SMK to develop production units as a medium for learning and entrepreneurship, so that in the long term, the institution can produce young entrepreneurs based more on the Minister of Education and Culture, 2013 [3]. The Production Unit is one of the media lessons at SMK which functions as a place of production (especially products and services). Entrepreneurial competence can be obtained through learning in the school production unit. Students learn 
how to produce goods / services that have economic value so that they can be marketed.

Increasing the abilities and skills of the young generation of prospective workers is the responsibility of the education world. To get students who are ready to work, eight main competencies are needed, namely a) critical communications skills; 2) critical and creative thinking; 3) inquiry / reasoning; 4) intrpersonal skills; 5) multicultural literacy; 6) problem solving; 7) digital literacy; 8) technological skills [9].Of the eight graduate competencies, competencies 1 to 6 are soft skills, while competencies 7 and 8 are hard skills.

Data from the Central Statistics Agency (CSA) states that the open unemployment rate (TPT) based on education, vocational schools (SMK) with growth reached $8.92 \%$. In February 2018 from $11.41 \%$ in February 2017. 2, 49\% of SMK graduates still have a high unemployment rate compared to other graduates. The Open Unemployment Rate (TPT) in DIY in February 2018 was $3.06 \%$. This increased by $0.22 \%$ points compared to the TPT in February 2017 of $2.84 \%$. The DIY TPT figure in February 2018 was lower than the National TPT of $5.13 \%$.

BPS DIY stated that the statistics received by residents who worked in DIY in February 2018 reached 2.076 million people, while the labor force in DIY in February 2018 was 2.142 million people. To overcome this, trust in each school is needed. Where parents and the government must trust the principal, the principal must trust the teacher to guide their students [2]. Through the production unit, students are expected to be able to develop their entrepreneurial spirit and develop their skills. Entrepreneurship is seen as the main driver of innovation, competitiveness and growth [6].

The use of production unit facilities and infrastructure to support teaching and learning activities has helped to achieve effective and efficient learning. [8], explained that the involvement of students in the production unit is not only to sharpen hard skills but also to manage soft skills. The production unit for vocational schools has a very important role in improving students 'knowledge and skills, nurturing students' entrepreneurial spirit and can generate economic benefits for schools. [8]. Of the 49 SMK in Bantul Regency, not all schools have production units, there are also some schools that have production units but have not used them optimally. Of the 49 schools, there are 8 schools that have carried out the production unit well (the schedule is routine, there are teachers involved, student involvement, but have not been able to fully train entrepreneurial students in terms of numbers and ideas).
Table 1: Types of School production units in Bantul Regency

\begin{tabular}{|c|c|c|}
\hline No & School & Type of business \\
\hline 1 & SMK Negeri 1 Bantul & $\begin{array}{l}\text { School canteen } \\
\text { managed by students }\end{array}$ \\
\hline 2 & SMK Negeri 1 Sewon & Food, Clothing \\
\hline 3 & SMK Negeri 2 Sewon & Batik business \\
\hline 4 & SMK Negeri 1 Pandak & Batik business \\
\hline 5 & $\begin{array}{lll}\text { SMK Negeri } & 1 \\
\text { Pajangan } & & \\
\end{array}$ & Craft business \\
\hline 6 & $\begin{array}{l}\text { SMK Muhammadiyah } \\
1 \text { Bantul }\end{array}$ & $\begin{array}{lr}\text { Trails } & \text { Business, } \\
\text { Automotive } & \text { Business } \\
\text { (Car Repair) } & \\
\end{array}$ \\
\hline 7 & $\begin{array}{l}\text { SMK Muhammadiyah } \\
2 \text { Bantul }\end{array}$ & Bike shop \\
\hline 8 & $\begin{array}{l}\text { SMK Muhammadiyah } \\
1 \text { Bambang Lipuro }\end{array}$ & Bike shop \\
\hline 9 & $\begin{array}{l}\text { SMK Muhammadiyah } \\
1 \text { Imogiri }\end{array}$ & Bike shop \\
\hline
\end{tabular}

(Based on observations to several schools in Bantul district) considerations carried out research are as follows: 1) The existence of the production unit of SMK in Bantul Regency has not yet spread. 2) Vocational High Schools that have organized or owned Production Units can improve their students' competencies and skills. 3) The existence of the Production Unit can increase community trust in vocational students who are able to develop their skills well. 4) For schools that already have production units, they can improve their facilities and infrastructure.

The success of an educational program through the teaching and learning process is strongly influenced by various factors, one of which is the existence of adequate educational facilities and infrastructure. In the production unit, students can learn to work like situations in the industry. To produce graduates who are ready to work, the production unit must have good management that supports learning. management of the production unit which consists of several management functions, namely (1) planning: at this stage it is necessary to set a clear vision, mission and objectives as a first step. establishment of production units and planning for procurement of production unit equipment and materials; (2) organization: the need for guidelines for organizational arrangements, organizational structure, and clear job descriptions to get the cohesiveness of the production unit manager; (3) implementation: the need for clear administrative records such as inventory, soup for the use of tools and materials and a schedule for the use of the production unit; (4) Supervision: for the sustainability of the production unit as a learning resource, it is necessary to supervise students, evaluate internal production units, and evaluate educational personnel. SMK Muhammadiyah 1 Bantul is a school that has a Production Unit Facility that has collaborated with a company, namely DAIHATSU. 


\section{METHOD}

This study uses a qualitative approach, a qualitative approach according to Corbin and Strauss is a form of research in which researchers collect and analyze data as part of the research process as participants with informants who provide data. This research is a qualitative case study research. Where case study research is the idea of a single case and will be described by several suitable methods [1]. Although there may be various specific objectives of the research question, the general aim is to develop an understanding of the case according to the keith punch in [11]. The structure of a case study must be a problem, context, problem, and lessons learned [13]. This research will contain descriptions, systematic, factual, and accurate descriptions of Production Unit Management as a learning resource at SMK Muhammadiyah 1 Bantul which includes 3 aspects, namely: production unit planning, Production Unit Implementation, and Production Unit Supervision. To achieve this, researchers must try to obtain and collect data that is in accordance with field conditions. Researchers use the questions of what, where, why and how. The question of how to be emphasized in this research is to explore the management of facilities and infrastructure for production units as a source of student learning. The how-to question is used to obtain information about the implementation of management such as implementation, organization and supervision. Furthermore, the results of the data were made as an example of schools in Bantul that did not yet have a production unit. For this reason, researchers must actively observe, observe, take notes, ask questions and record in gathering information related to this research. The place of this research is SMK Muhammadiyah 1 Bantul, which is addressed at. Jalan Parangtritis Km 12, Manding, Trirenggo, Bantul. The reason for choosing a research location at SMK Muhammadiyah Imogiri and SMK Muhammadiyah 1 Bantul is because the school is one of 49 SMK in Bantul Regency which implements the Production Unit program. This location was chosen because it has been carrying out the production unit for more than 3 years and there are various variations of the production unit in one school. So that researchers are interested in determining this location as a research location. The main data sources of this study were the principal, Waka Sarana and Prasarsna, the school's production unit coordinator or staff, as well as students involved in the implementation of the production unit who became research informants / subjects. The data collected is in the form of their expressions / opinions / perceptions about all things related to the program being implemented. Therefore, the type of data in this study is primary data. The research subjects were determined by a purposive sampling model. The principal and coordinator of the school's Production Unit are 1 person each in each school. Meanwhile, the Production Unit coordinator at the department level is adjusted to the number of departments that have production unit activities. Meanwhile, students who become respondents are students who have been involved in production unit activities at school and have not graduated / left school. The author uses secondary data in the form of the school profile under study. When viewed from the data source, data collection can use primary and secondary sources. Furthermore, when viewed in terms of data collection methods or techniques, data collection techniques can be carried out by observation, interview, documentation and a combination of the four [12]. In this study, the interviews used were free interviews and structured interviews. Free interviews were used when conducting the preliminary study, while structured interviews were used when collecting data on the management of production unit facilities and infrastructure at SMK Muhammadiyah 1 Bantul and which included planning, organizing, implementing and supervising the production unit of the school. The subjects interviewed by the school principal, productive teacher, coordinator or school production unit staff. The instrument used as an observation guide was developed from structured interview guidelines. This direct observation is carried out to obtain an objective picture in the field of planning, procurement, inventory, maintenance, utilization, and the elimination of facilities and infrastructure for the production unit of SMK Muhamadiyah 1 Bantul. Sources of data from the documentation in this study include: photos of interviews with respondents, photos of production facilities at SMK Muhamadiyah 1 Bantul and the vision and mission of the production units in the two schools. In this study, researchers used data collection instruments to obtain data about production unit management as a learning resource at SMK Muhammadiyah 1 Bantul. Researchers use inspection techniques by utilizing sources. Triangulation with sources means comparing and cross-checking the degree of confidence of information obtained through different time and tools in qualitative research. In this study, researchers used different techniques, namely interviews, observations and documents by comparing and checking back the degree of confidence of information obtained through different times and checking data by comparing and double-checking data obtained from one respondent with another.

\section{RESULTS AND DISCUSSION}

\subsection{Authorized Musaba Infrastructure Procurement Planning}

According to the head of the department and deputy director of the infrastructure facilities at SMK Muhammadiyah 1 Bantul, the planning process for infrastructure and facilities in the provision of 
infrastructure at the Authorized Musaba is adjusted to the standards issued by the government and the standards of the partner (Dihatsu). After that it was adjusted to the conditions and lack of infrastructure at the Authorized Musaba. Procurement planning is submitted by the technician (toolman), the technician will provide data on the shortage of tools and practice materials to the chief engineer then the head of the department will sort the needs for tools and materials according to the most important interests and adjusted to the existing budget. Usually the budgeted funds are not sufficient with the required interests. After there is a budget and equipment needs have been recorded, the management of the production unit will form a shopping team in charge of the procurement of equipment and goods. The planning stage for the infrastructure of the Vocational High School Authorized Production Unit is said to be successful if it meets the following requirements. In planning there must be documents regarding: a) Formulation of vision and mission, b) Plan for material requirements, c) Budget plan, c) Organizing plan, d) Monitoring plan.

\subsection{Organizing "Musaba Authorized"}

The organization was based on the 2007 Dikmenjur, where the head of the UP or the head of the production unit was at the top and was assisted by other staff, such as technicians, the mechanical section, the ferromagnetic section [3]. The organizational structure of the Authorized Musaba can be seen in the image below:

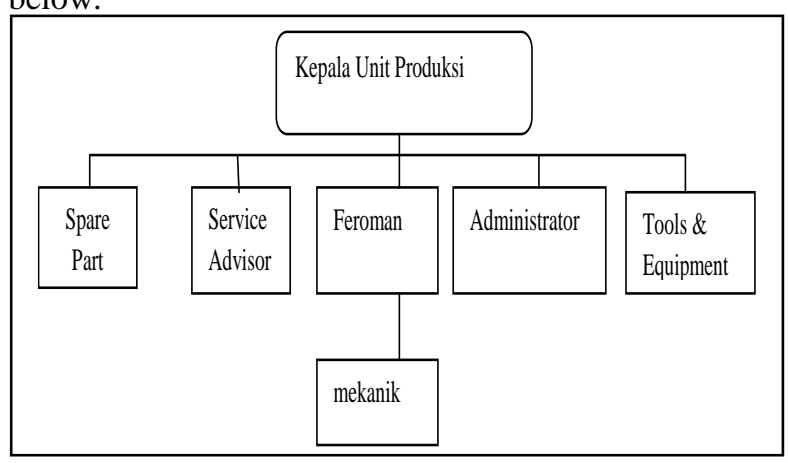

Figure 1: Authorized musaba organizational structure

The division of tasks in the Authorized musaba is in accordance with the job descriptions that have been made. The division of job descriptions makes it easier to carry out the duties and responsibilities of each - so that jobs can understand what work needs to be done. The work mechanism is adjusted to the job description to find out the duties and responsibilities.

\subsection{Implementation of Infrastructure "musaba Authorized"}

The implementation of the procurement of facilities and infrastructure is adjusted to the planning for the procurement of tools and materials. The procurement of facilities and infrastructure for Musaba authorized has a working partner, namely Daihatsu. The production unit will buy according to the ability and needs which are prioritized and considered with input from partners. Aspects of success that can be used as a reference for assessing the implementation of infrastructure include: a) The implementation of the infrastructure program must be in accordance with the plan, b) All members of the organization must carry out their duties and obligations in accordance with the job description, c) Implementation of the activities of the facilities and infrastructure for the head of the production unit, technicians, subject teachers and students, d) There are guidelines for the use of tools. There is administration in the form of books or cards, e) Inventory of tools and machines, f) Maintenance cards, g) Material receipts. Technique for infrastructure and infrastructure procurement is good. This is evidenced by the provision of facilities and infrastructure that are in accordance with the standards of work instructions in the 2007 Directorate General of Education regulations[3]. The use of tools and machines at musaba authorized production units is very good because it has guidelines for the use of tools and machines. Every procurement of tools and machines is included with usage pemodaman so that the use of machines and tools is used in accordance with predetermined work functions. Inventory of tools and materials for authorized musaba is carried out after the procurement of tools and materials has been verified. Every teacher and student who practices has a reference, so that in carrying out the practice it is adjusted to the book. Activities at the Musaba authorized production unit are carried out according to the schedule of activities. The activity schedule consists of three activities, namely learning, apprenticeship and authorized musaba service activities every Saturday and Sunday so that if there are customers who come they do not interfere with the teaching and learning activities.

\subsection{Supervision of authorized musaba facilities infrastructure}

Supervision in the authorized musaba production unit who is responsible is the head of the production unit, wakasek for infrastructure, school principals and work partners (Daihatsu). Supervision is carried out every day (head of the production unit) when the production unit operates. In supervision, usually attention is paid to the maintenance of tools and materials such as cleanliness which is always emphasized on each student after practicing. In addition, supervision at authorized musaba is carried out periodically, once a week or once a month as well as every semester to directly check the condition of the production unit. During supervision, if there is damage 
or accident, it is immediately recorded and reported to the head of the production unit.

\subsection{Use of the Production Unit as a Learning Source}

With good management of facilities and infrastructure in both schools, it results in the readiness of the practical tools used by students both in the learning process and in the student apprenticeship process. In accordance with the function of the production unit, namely as a source of student learning if the management goes well, the practical activities will run smoothly. Thus, students are expected to be better prepared to engage directly in the industrial and business world after graduating from SMK later. Next I convey the results of observations and closed questionnaires to students in both junior high schools as follows:

Table 2: Authorized musaba production unit usability table

\begin{tabular}{lccc}
\hline Observed aspects & $\begin{array}{l}\text { Total } \\
\text { score }\end{array}$ & Percentage & Category \\
\hline $\begin{array}{l}\text { SOP implementation } \\
\text { during practice }\end{array}$ & 88 & $92 \%$ & $\begin{array}{l}\text { Very } \\
\text { well }\end{array}$ \\
\hline $\begin{array}{l}\text { knowledge skills and } \\
\text { practical tools }\end{array}$ & 195 & $97 \%$ & $\begin{array}{l}\text { Very } \\
\text { well }\end{array}$ \\
\hline $\begin{array}{l}\text { guidance from the } \\
\text { executor of the } \\
\text { production unit }\end{array}$ & 91 & $95 \%$ & $\begin{array}{l}\text { Very } \\
\text { well }\end{array}$ \\
\hline $\begin{array}{l}\text { maximize knowledge in } \\
\text { selecting materials } \\
\text { according to market } \\
\text { standards } 93\end{array}$ & $97 \%$ & $\begin{array}{l}\text { Very } \\
\text { well }\end{array}$ \\
\hline $\begin{array}{l}\text { skilled in the use of } \\
\text { tools or machines }\end{array}$ & 119 & $93 \%$ & $\begin{array}{l}\text { Very } \\
\text { well }\end{array}$ \\
\hline $\begin{array}{l}\text { understand the theory } \\
\text { after practice in the } \\
\text { production unit }\end{array}$ & 27 & $84 \%$ & $\begin{array}{l}\text { Very } \\
\text { well }\end{array}$ \\
\hline
\end{tabular}

The SMK production unit infrastructure management model is a Production Unit management model that can be carried out by SMKs so as to maximize the potential of students, teachers and schools to produce graduates who are ready to work and generate income. The management of SMK production unit facilities and infrastructure has been tested qualitatively and the results show that this model is clear, practical and suitable for the development of Production Units.

The existence of a production unit equipped with good and quality infrastructure can help students have more skills than students who only practice in workshops and do not meet directly with consumers. when the facilities are met, the management must also be good so that the facilities obtained by students will be maintained in the long term. For this reason, a hypothetical model can be formulated using the production unit as a source of student learning. The hypothetical model of the utilization of the production unit focuses on student learning resources. The components of the production unit as a learning resource consist of four aspects of management, namely: (1) planning consisting of a clear vision, mission, and objectives as the initial step of planning the production unit; (2) the organization consists of guidelines for organizational arrangement, organizational structure, work mechanisms and job descriptions, (3) implementation consists of the division of tasks for teachers and educators, learning tools, and learning rules; (4) supervision consists of supervision of students, internal evaluation of the production unit and evaluation of educators and personnel. The SMK production unit infrastructure management model is a Production Unit management model that can be carried out by SMKs so as to maximize the potential of students, teachers, and schools to produce graduates who are ready to work and generate income. The management of SMK production unit facilities and infrastructure has been tested qualitatively and the results show that this model is clear, practical and suitable for the development of Production Units. The explanation and characteristics of the management infrastructure for the smk production unit as a source of student learning can be seen in the following figure:

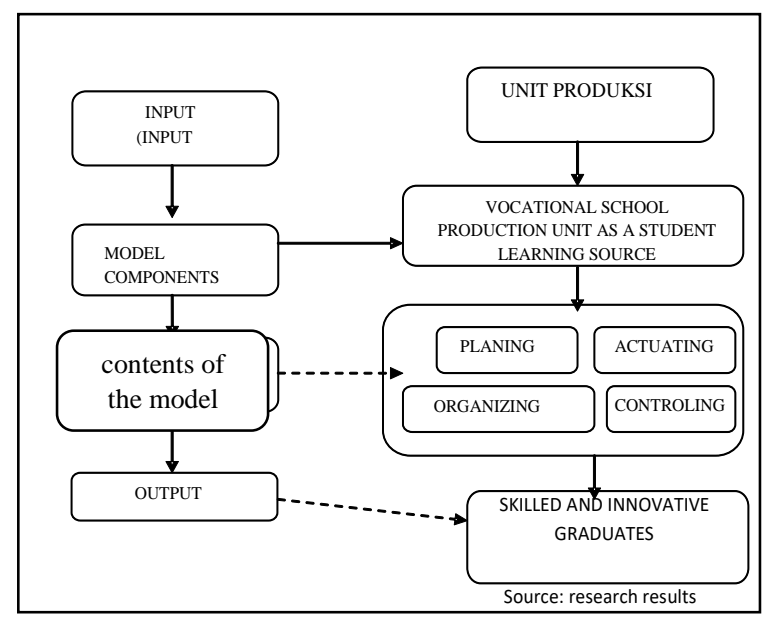

Figure 2: Concept of Production Unit Management Model

The pattern above can be explained that producing graduates who are ready to work to improve the welfare of their citizens can be done through the Production Unit as a learning resource. Each stage will go through four stages of management including planning, organizing, implementing and monitoring. This can be described as follows:

Input (students) with a variety of skills that are still not maximally honed and are assisted by the production unit as a forum for students to learn the practical process and development of entrepreneurial culture in SMA as well as forge close cooperation with the industrial 
world. It is hoped that with the production unit students will be able to develop their abilities.

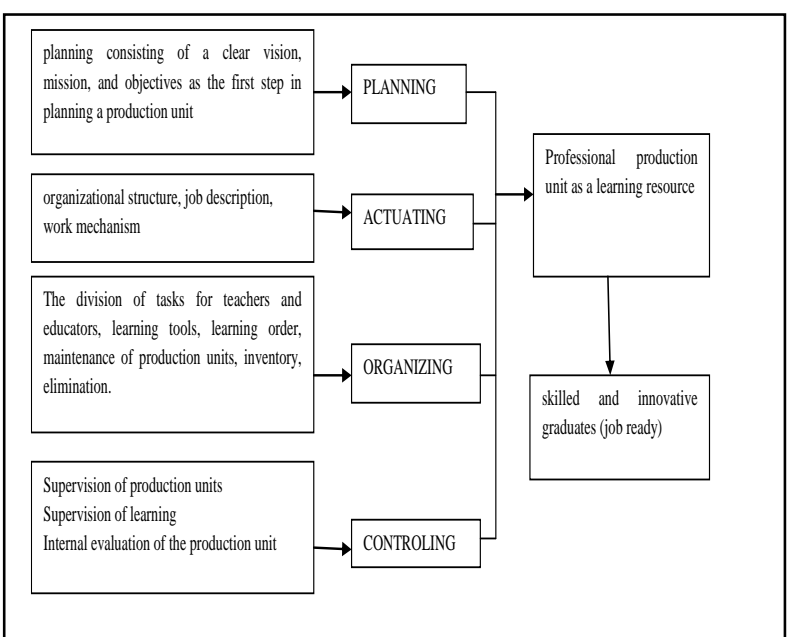

Figure 3: Concept of Hypothetical Model of Production Unit Utilization as Learning Source

The components of the production unit model as a source of student learning, the production unit in the school environment functions as (1) a production-based training vehicle for students; (2) a vehicle for cultivating and developing an entrepreneurial spirit in Vocational High School students; (3) productive practice directly for students.

Process (production unit management) which includes: 1. Planning for school production units in Vocational High Schools in this case learning planning includes a) planning work programs for the two businesses in each school, namely Authorized musaba and imothec workshops; (b) not all skill competencies are practiced in school production units; (c) the teacher makes a practical learning implementation plan (RPP); (d) involving teachers and students in activities in the production unit. 2. Organizing school production units in Vocational High Schools has organized by fulfilling aspects in the preparation of school production units such as forming an organizational structure for school production units along with the division of tasks and responsibilities in practically carrying out their respective duties according to directions even though not in the describe in writing the job description. 3 . Implementation of school production units that have implemented production units which include several aspects, namely implementing activity plans in the production unit, carrying out the steps taken in achieving entrepreneurial goals, carrying out the division of tasks and responsibilities of personnel involved in the school production unit, managing time, Maintenance of the inventory production unit has been going quite well. 4. Supervision of the school production unit has carried out supervision, Supervision activities carried out in the production unit are not only carried out by the teacher and the head of the production unit but also inviting supervisors or committees or other interested parties to monitor, assess and provide suggestions for improving the management of the production unit in the context of improve the quality of production output at least at the end of each semester.

The output with the existence of a professional production unit is expected to create students who apply an independent, disciplined and creative spirit so as to create work-ready graduates. Supporting factors for the management of the school production unit include: (a) the willingness of the activity implementers in the production unit (b) professional teaching staff, (c) sufficient capital resources. It is hoped that when the management of the production unit runs well, a professional production unit will be created so that it can be used as a source of student learning and produce graduates who are skilled, innovative and able to compete in the world of work.

\section{CONCLUSION}

To produce graduates who are ready to work to improve the welfare of their citizens, this can be done through the Production Unit as a learning resource. Each stage will go through four stages of management, namely planning, organizing, implementing and monitoring. The availability of good infrastructure will support the success of the learning process. Where is the learning process at SMK Muhammadiyah 1 Bantul, especially the Light Vehicle Engineering department which already has a Production Unit as a medium or student practice place. From the results of the research we can conclude that: (1) Production Unit Planning at SMK Muhammadiyah 1 Bantul, especially the Light Vehicle Engineering study program (both Motorcycle and Car Workshop Production Units) can run according to predetermined procedures, namely starting with budget planning, planning needs goods and materials of the Production Unit, the planning of the Production Unit usage schedule, the organizing plan, and the implementation plan, so that the planning of the facilities and infrastructure for the Production Unit of SMK Muhammadiyah 1 Bantul is quite good. (2) The organization of the two Production Units can run well because of the work organizational structure and work mechanism can go well. The organizing process begins with the creation of an organizational structure and division of tasks in accordance with the job description, so that the organization runs well. (3) Implementation, especially in the Authorized Musaba Production Unit, goes well in accordance with The division of tasks for teachers and educators, learning tools, learning order, maintenance of production units, inventory, elimination. (4) Supervision of practical facilities and infrastructure is carried out by the head of the Production Unit on a regular basis, assisted by technicians and teachers of practical subjects who work in the workshop every day. 
If there is damage or loss of the available practical infrastructure, the technician will report it to the head of the Production Unit and then repair it. (5) Development of a hypothetical model of the utilization of Production Units is expected to be a solution as a learning resource for creating skilled and innovative graduates. The results showed that the use of tools and goods in the two production units did not pay attention to the existence of written regulations where there were those who did not use them. Lack of promotion regarding the existence of the Production Unit to the surrounding community so that the production unit is still focused on the school community and residents around the school, Lack of cooperation with related government parties so that the development of the production unit is slightly hampered by the problem of funding and the provision of infrastructure that prioritizes quality. In order to achieve better results and create superior students in the field of Light Vehicle engineering expertise, the management of Production Unit infrastructure at Authorized Musaba needs to be considered, is when the use of tools and goods must prioritize safety, both students and technicians are expected to continue wearing security equipment. In addition, the development of the production unit will run well if it is supported by the promotion of the production unit through social media and school partners and related work partners, thereby increasing public confidence to be interested in using repair services in the two production units.

\section{REFERENCES}

[1] Anselm Straus dan Juliet Corbin, 2013, Dasardasar Penelitian Kualitatif, Yogyakarta: Pustaka Pelajar.

[2] Antony Seldon, 2010, An end to factory schools, ISBN No. 978-1-906996-19-2

[3] dikmenjur (2007) '10-kode-a1-10-manajemen-unitproduksijasa-sbg-sumber-belajar-siswa-danpenggalian-d (3)'.
[4] Silverman, D. (2013). Doing Qualitative Research (4th ed.). (K. Metzier, Penyunt.) SAGE Publications

[5] Sumual, H. and Sumual, H. M. (2017) 'Production Unit of Vocational High School: Learning Resource and Enterpreneurships Place', Innovation of Vocational Technology Education. doi: 10.17509/invotec.v12i2.6204.

[6] Karen Wilson, 2008, Enterpreneurship Education In Europe Chapter 5, ISBN No 978264044098

[7] Top, S., Çolakoğlu, N. and Dilek, S. (2012) 'Evaluating Entrepreneurship Intentions of Vocational High School Pupils Based On SelfEfficacy Concept', Procedia - Social and Behavioral Sciences. doi: 10.1016/j.sbspro.2012.09.1072

[8] Widiyati Erna (2015). Pengelolaan Unit Produksi di SMK Negeri 1 Klaten. Universitas Muhammadiyah Surakarta.

[9] Martin Lackeus, 2015, Enterpreneurship In Education, Europe an Commission, OECD

[10] Sumaryani, S. (2018) 'Model development of production management unit to enhance entrepreneurship attitude of vocational school students from fashion department', in AIP Conference Proceedings. doi: 10.1063/1.5028113.

[11] Silverman, D. (2013). Doing Qualitative Research (4th ed.). (K. Metzier, Penyunt.) SAGE Publications

[12] Sugiyono, P. D. (2015) 'Statiska untuk Penelitian', in Statiska untuk penelitian.

[13] Creswell, J. W. (2015). Penelitian kualitatif dan desain riset. Yogyakarta: Pustaka Pelajar. 